\title{
Short CVs of Contributors to the Special Issue
}

\section{Michiel C Bekker}

Michiel (Giel) Bekker is a senior lecturer in Project Management in the Graduate School of Technology Management, University of Pretoria, South Africa. He is also an Erasmus Mundus Scholar at Umea Business School, Sweden and Herriot Watt University, Edinburgh, Scotland. He is a Registered Professional Engineer and holds an M.Eng (Mechanical), MBA and PhD from the University of Pretoria. His research interests are in project governance, project complexity and large capital project performance. He is also a recipient of the Project Management Excellence Award in Project Execution from the Project Management Institute of South Africa.

\section{Kai-Ying Chan}

Kai-Ying (Alice) Chan is a Senior Lecturer in the Graduate School of Technology Management at University of Pretoria, South Africa. She holds a PhD from University of Pretoria (2010). Her PhD research focused on organizational networks and firm innovation in a Science Park. Her current research topics include project teams, innovative activities and performance. She is currently one of the researchers in the DFID project with the focus on South African innovation.

\section{Tsun-Jin Chang}

Tsun-Jin Chang is an associate professor in the Department of Marketing Management at Shih Chien University, Kaohsiung Campus, Taiwan. He received a BSc in Business Administration from Tam Kang University, and an MBA and a PhD in Management from the Institute of Business Management of National Sun Yat-Sen University, Taiwan. His current research interests include organizational innovation, new product innovativeness, cross-functional new product development (NPD) teams, R\&D-marketing interface, and employee creativity.

\begin{abstract}
Anna Jerbrant
Anna Jerbrant is an associate professor in the Department of Industrial Economics and Management, at The Royal Institute of Technology (KTH, Sweden). Anna holds a PhD degree from KTH (2009). Her research is focused on increasing the understanding of the organizational challenges that contemporary project-based organizations face with increased competition in a globalized world. The findings emphasize the importance for the multi-project management to focus on the balance between creativity, flexibility and structure. Anna has published several articles in the International Journal of Project Management, The International Journal of Managing Projects in Business and the International Journal of Project Organization and Management.
\end{abstract}

\section{Frien van Kessel}

Frien van Kessel is a tenured lecturer of the International Business School of Fontys University of Applied Sciences in Venlo, the Netherlands. As an external doctoral student he is linked to the Department of Organization Studies at Tilburg University, the Netherlands. His dissertation focuses on the role of intra-organizational environments for creativity and innovation outcomes.

\section{Monica Lindgren}

Monica Lindgren is Professor of Industrial Economics and Management at the School of Industrial Engineering and Management, KTH Royal Institute of Technology, Stockholm, Sweden. Prof. Lindgren's research interests are located within the general area of critical organization studies and include project-based work, entrepreneurship, gender and leadership. Her research has been published in Journal of Management Studies, Human Relations, Scandinavian Journal of Management and Ephemera: theory \& politics in organization. She is a member of the team behind the international Making Projects Critical workshop series. 


\section{Leon Oerlemans}

Leon Oerlemans is professor of Organizational Dynamics in the Department of Organization Studies at Tilburg University, the Netherlands. He is also extraordinary professor Economics of Innovation at the University of Pretoria, Graduate School of Technology Management, South Africa and co-founder and core fellow of the Center for Innovation Research at Tilburg University. Research topics include temporary organizations, interactive learning and interorganizational relationships and networks. Amoungst others, his work has been published in Journal of Management, Research Policy, Organization Studies and Technovation.

\section{Johann Packendorff}

Johann Packendorff is associate professor in Industrial Economics and Management at the School of Industrial Engineering and Management, KTH Royal Institute of Technology, Stockholm. His research explores issues related to project management, entrepreneurship and leadership. Dr Packendorff's research has been published in Journal of Management Studies, Human Relations, Scandinavian Journal of Management and International Journal of Project Management. He is a member of the team behind the international Making Projects Critical workshop series, and a board member of the Swedish Project Academy.

\section{Tinus Pretorius}

Tinus Pretorius is professor of Technology Management in the Department of Engineering and Technology Management and is also chairperson of the Graduate School of Technology at the University of Pretoria in South Africa. He holds a $\mathrm{PhD}$ in Engineering with specialization in Technology Management. His research focuses on technology and innovation management and includes project management strategy as one of his areas of interest. He is a rated researcher and published in various international journals (e.g. Technovation, South African Journal of Science) and conference proceedings. He is also a registered professional engineer, fellow of the SA Engineering Academy and a member of the IEEE.

\section{Saskia van Stroe}

Saskia van Stroe is a professor in Sustainable Innovation in the International Business School of Fontys University of Applied Sciences in Venlo, the Netherlands. She holds a PhD in Chemical Engineering from Eindhoven University of Technology, the Netherlands. Previously, she worked as an R\&D project manager and as a head of Consumer and Market Insight at Unilever; and as strategic marketing manager at D\&M Europa. Currently, she also works as a management consultant at Smart Group Organization Advice.

\section{Shang-Pao Yeh}

Shang-Pao Yeh is professor of Tourism in the Department of Tourism at I-Shou University, Taiwan. He is also the editor-in-chief of Annals of Leisure and Recreation Research. He holds a Doctor of Management from Webster University, a Master of Public Administration from University of Southern California, and a MBA from Northrop University. His current interests of research are knowledge management, human resource management, and strategic management in tourism and hospitality industry. 